\title{
Elämän kokoinen monivärimaalaus sosiaalipedagogiikasta
}

Leena Kurki

Kohtaamisen voima. Sosiaalipedagogin elämä ja teokset

Basam Books, Helsinki 2021

Susanna Leimio

$\mathrm{K}$

ohtaamisen voima (2021) on dosentti Leena Kurjen sosiaalipedagoginen monivärimaalaus ja kokoomateos. Se on myös kasvutarina ja aikamatka siihen, kuka ja mitä hän on ja miten hän on siihen tullut. Kirja on kertomus ihmisestä, ammattilaisesta, asiantuntijasta ja innostajasta. Se on kertomus Kurjen sosiaalipedagogisesta kasvusta eri kulttuureissa, uskonnoissa, koulutuksessa, johtamisessa sekä monissa muissa arjen toimintaympäristöissä. Kirja tempaa lukijansa mukaan paikoin varsin seikkaperäiseen kertomukseen kirjoittajan elämästä ja kokemuksista sekä niiden toisiaan rakentavasta luonteesta niin henkilökohtaisessa kuin työnkin maailmassa. He, jotka Leenan tuntevat, lukevat kirjaa ja saavat samanaikaisesti kokemuksen äänikirjan kuuntelemisesta: ilotulitteiden tapaan värikäs, kuvaileva tyyli ja sanoissa kaikuva Leenan ääni kuljettavat lukijan matkalle maasta, kirjasta, persoonasta ja kokemuksesta toiseen. Minut se palautti muistoissani takaisin Tampereen yliopistoon, kevään 1999 oppitunnille, josta ei ollut enää paluuta entiseen. 


\section{Tarina, joka ansaitsee tulla kuulluksi}

Kirja alkaa kriittisellä pohdiskelulla halusta, oikeudesta ja koetusta pakosta kirjoittaa kirjaan painetut lauseet. Kirjailija puhuu tarpeesta tulla kohdelluksi ja kuulluksi omana itsenään. Hän myös tuo esiin näkökulmia, jotka eivät aikaisemmin ole tulleet riittävän painokkaasti ilmi suhteessa häneen ja hänen tuotantoonsa. Kirja on omaelämäkerrallista, akateemisesti värittynyttä mutta helppolukuista kerrontaa siitä, kuka Leena Kurki persoonana on ja millaisia valintoja hän on tehnyt elämänsä aikana. Teksti johdattaa lukijansa kirjailijan lapsuuden ja varhaisen koulutus- ja työhistorian uumeniin ja nostaa esiin sosiaalipedagogisesti kiinnostavan ymmärryksen: emme ole historiastamme vapaita. Kaikki kokemamme kasvattaa meitä kerros kerrokselta kohti sitä, mihin lopulta päädymme, miksi lopulta tulemme ja mitä lopulta olemme.

Kirja paljastaa, että Leena Kurki elää, kuten itse on opettanut. Lukuisiin kohtaamisiin nojaavaa teosta leikkaa läpi ymmärrys ihmisestä arvokkaana ja ainutlaatuisena, alati kehittyvänä ja yhteisöissään täydellistyvänä persoonana. Persoona säilyy samana läpi elämän. Omiin innostajiinsa ja inspiraationsa lähteisiin nojaten Kurki toteaa: "Olemme osiemme summa, yhteydessä yhteiskuntaan, yhteisöihin ja yksilöihin.” Tätä inhimillisesti kiinnostavaa ymmärrystä ja ihmiskäsitystä Kurki kuljettaa mukanaan elämänsä matkoilla vuodesta toiseen. Hän rakentaa ymmärrystään kokemustensa kautta. Hän aistii herkästi ja voimakkaasti olosuhteet ja muutokset ympärillään. Hänen uudistushaluinen ja toisaalta menneisiin vahvasti juurtuva näkemyksensä ei ole kasvanut vain myötätuulessa. Tiedetään, että koetultuna heikoimmastakin versosta kasvaa omilla juurillaan seisova puu.

\section{Minun, sinun vai meidän?}

Tieteellisen ajattelun luonteeseen kuuluu sen rakentuminen, kehitys ja eteenpäin meneminen. On myös luonnollista, että osa teorioista jää vahvemmin elämään kuin jotkut toiset. Tunnustelua-otsikolla kulkeva luku ottaa vahvasti kantaa sosiaalipedagogisen teorian kehitykseen. Se pohtii kirjailijalle merkityksellisen sosiokulttuurisen innostamisen asemaa suomalaisen sosiaalipedagogiikan kentässä ja toteaa, hieman surumielisesti, sen jääneen marginaaliin. Kirjailija myös avaa joitakin haastavia kohtaamisia ja kysyy: "Vaikuttaako ammatillisuuden korostaminen siihen, että innostamisen henki ja elämä häviävät?" Kirjan sivuilta esiin nousevat sy- 
väluotaavat kysymykset johdattavat lukijan ammatillisen yliopistotodellisuuden arkeen. Osin riveiltä ja toisaalta niiden väleistä voi lukea, millaista valtaa teoriat ja niitä edustavat henkilöt käyttävät, ja mitä jos teoriat eivät tavoitakaan todellista elämismaailmaa. Kirjailija kysyy: Jos sosiaalipedagogisessa ajattelussa luovumme sosiokulttuurisesta innostamisesta, kapeutuuko ihmiskäsityksemme? Luovummeko jostakin hurjan arvokkaasta, ja tyydymme samaan aikaan johonkin ihmisestä etäiseen ymmärrykseen? Johtaako se kylmään ja koleaan, rakenteelliseen, ihmisistä vähemmän välittävään tapaan ajatella, toimia, olla ja elää?

Käytännön kentällä sosiokulttuurinen innostaminen jatkaa vahvana omaa elämäänsä. Säilyäkseen se tarvitsee kuitenkin kehittyvää teoriaa, ja silloin sen luontaiset juuret ovat juuri sosiaalipedagogiikassa. Sitä yhteyttä toivon vaalittavan. Keväällä 2021 julkaistu Päijät-Hämeen ehkäisevän työn toimintakertomus (Leimio 2021a) vastasi tarpeeseen ja syntyi aidossa dialogissa eri osapuolten kesken. Kehittämisprosessi fasilitoitiin sosiokulttuuriseen innostamiseen tukeutuen. Se alkoi herkistymisestä olosuhteille monipuolisesti kerätyn tiedon pohjalta. Runsasta tietoa ymmärrettiin yhdessä, mikä oli omiaan vahvistamaan motivaatiota tehdä asioille jotakin. Toimintakertomuksen pohjalta laadittiin alueellisesti ja neljän ilmiön (päihteiden käyttö, mielenterveys, ongelmapelaaminen ja lähisuhdeväkivalta) ehkäisyn kannalta kattava suunnitelma tavoitteineen, toimenpiteineen ja mittareineen. (Haavisto 2021.) Suunnitelman toimeenpanoon ja toteutukseen ollaan laajasti sitoutuneita. Hyvinvointihyödyn keskiössä on alueen asukas.

Tiiviissä ajattelun ja toiminnan vuorovaikutuksessa toimien Päijät-Hämeen ehkäisevässä työssä päästiin pidemmälle kuin koskaan aikaisemmin. Joulukuussa 2021 hyväksyttäväksi esitettiin yhteisen tiedon ja ymmärryksen pohjalta laadittu toimintasuunnitelma (Leimio 2021b), joka ensimmäistä kertaa tavoittaa jotakin näkyvien ilmiöiden takaa. Se avaa yhteisen näkymän ilmiöiden suoja- ja riskitekijöihin sekä niiden juurisyihin. Siten se myös antaa mahdollisuuden uusien, hyvinvointia, terveyttä ja turvallisuutta edistävien vaikuttavuusketjujen syntymiselle.

\section{Kohtaamiset matkoilla eivät ole sattumaa}

Kohtaamisen voima -kirja johdattaa lukijan Oulun ja Tampereen kautta moniin kaupunkeihin ympäri maailman. Mukana matkoilla kulkevat lukuisat suuret teoreetikot ja käytäntöjen rakentajat. Tekijät, näkijät ja kokijat täydentävät kukin osaltaan kirjailijan ymmärrystä ja teoriaa sosiaa- 
lipedagogiikasta. Merkittävän rooliin saavat mm. Marcuse, Macchiavelli, Christie, Tönnies, Addams, Freire, Buber, Mounier, Starratt, Quintana ja Gillet. Kurki nostaa keskeiseen asemaan myös jesuiitat, Pablo Escobarin, romanit, saamelaiset sekä suomalaiset Antti Eskolan, Vihreän liikkeen ja setlementtityön. Lukijalle syntyy ymmärrys siitä, että kurkilainen sosiaalipedagogiikka saa voimansa ja värinsä lukuisista kohtaamisista vuoropuhelussa edellä mainittujen ja monien muiden, enemmän ja vähemmän tunnettujen, tahojen kanssa.

Toisessa luvussa lukijoille avautuu näkökulma Leena Kurjen varhaiseen tieteelliseen heräämiseen, ja siihen, miten käytäntö vie tieteentekijän kohti teorioita. Tarve saada vastauksia ja syventää osaamistaan dialogissa teorioiden kanssa johti kirjailijan Oulun yliopistoon ja myös väitöskirjan tekemiseen. Tämä elämänvaihe avaa kirjailijalle näköalan yhteisöihin ja aistiherkkyyteen, spritualiteettiin, joka puhaltaa hengen itse tekemiseen. Kohtaamisen voima -kirjassa jesuiitat ja heidän ajattelu- ja toimintatapansa nousevat keskiöön Kurjen ymmärryksen ja ajattelun kehityksessä. Pelätty ja kunnioitettu, kasvatuksessaan vahvasti moraaliin nojaava, maailmanlaajuinen järjestö onnistui kirjailijan mukaan yhdistämään teorian ja käytännön harmoniseksi kokonaisuudeksi. Siinä osallistaminen, kriittisyys ja humanismi olivat toiminnan syvintä ydintä. Maailmanmatkailija tutustui jesuiittojen toimintaan mm. Itävallassa, Italiassa ja Irlannissa ja toi tuliaisina Suomeen mm. väittelyn opetusmenetelmänä.

Kolmannessa luvussa seurataan Leena Kurjen elämänmatkaa Tampereelta Kolumbiaan, Intiaan ja Yhdysvaltoihin. Kiehtova ja kiinnostava tarina tempaa mukaansa ja tarjoaa lukijalle välähdyksiä esimerkiksi Pablo Escobarin ja sissien elämästä. Luku lisää myös ymmärrystä kurkilaisen sosiaalipedagogiikan kehityksestä erityisesti ignatiaanisen pedagogiikan ja ranskalaisen persoonakeskeisen kasvatuksen sekä spiritualiteetin näkökulmista. Tässä luvussa kuvaillaan yksilön ja persoonan välisiä eroja ja yhteyksiä. Siinä kerrotaan ihmisen olemassaolosta ja tavasta olla yksilöllisessä, ainutlaatuisessa ja henkilökohtaisessakin suhteessa toiseuteen. Pohdinnat henkisyydestä ja kuvaukset intialaisesta filosofiasta johdattavat, ainakin minut lukijana, tähän päivään ja ihmisten tapaan olla läsnä toisillensa. Kuten Kurki kirjassaan toteaa: "Todelliset ja väärentämättömät suhteet ihmisten välillä voivat syntyä vain luonnollisissa ja vilpittömissä kohtaamisissa.” Ymmärrän, että luonnollisuus ja vilpittömyys vaativat ihmiseltä paljon, kuten olla sinut itsensä kanssa ja ymmärtää itseään omasta elämänhistoriastaan käsin. Kaikki meistä eivät koskaan tavoita sellaista 
olemisen muotoa, rauhaa ja vapautta oman mielensä tasolla. Nämä spiritualiteettipohdinnat muodostivat lopulta myös Kurjen johtajuusajattelun perustan.

Neljäs ja viides luku muodostavat yhden, nähdäkseni varsin keskeisen etapin sekä kirjailijan elämässä, että suomalaisen sosiaalipedagogiikan kehityksessä. Luvuissa kuvataan, miten sosiaalipedagogiikka, sosiokulttuurinen innostaminen ja erityisesti personalistinen sosiaalipedagogiikka juurtuivat Tampereen yliopiston opetukseen ja kukoistivat siellä aikansa. Oppikokonaisuus ponnisti kasvatustieteen laitokselta ja nuorisotyön koulutusohjelmasta ja asettui lopulta sosiaalityön yhteyteen, ilmeisesti vastoin kirjailijan näkemyksiä. Monista näkemyksellisistä haasteista huolimatta Kurki haki lisäoppia ja entistä syvempää syvyyttä ymmärrykseensä Espanjasta ja Ranskasta. Hän kirjoitti useamman kirjan ja artikkelin sosiokulttuurisesta innostamisesta ja sai sen juurtumaan opetusohjelmaan meidän opiskelijoiden onneksi. Kirjasta voi lukea hyvin innostavan ja kiinnostavan katsauksen tähän upeaan vaiheeseen, siihen, miten persoonat, yhteisöt, dialogisuus ja aidot suhteet täydensivät kirjailijan sosiaalipedagogista ymmärrystä entisestään.

Luvuissa myös paljastuu myöhemmin aiheen ympärille syntyneet jännitteet ja yksi näkemys siitä, miten monia innostanut tutkintokokonaisuus oli päätetty lakkauttaa. Sosiaalipedagogiikan opetus sai päätöksen jälkeen jatkua vielä hetken omaa linjaa suppeampana sivuainekokonaisuutena, jonka saattoi valita osaksi mitä tahansa tutkintoa. En voi välttyä surun tunteelta lukiessani siitä, miten Leena Kurki joutui lopulta päästämään irti rakkaasta lapsestaan. Toisaalta me Kurjen opetuslapset, tai ainakin osa meistä, jatkamme perinnön kuljettamista eteenpäin. Käytäntö tarvitsee juuri tällaista, vahvasta teoriasta ponnistavaa orientaatiota. Teorioita ja käytäntöjä ei yksinkertaisesti voi tai pidä kuljettaa toisistaan irrallisina.

\section{"Hän kyllä kuuntelee, mutta ei kuule kertojan todellista tarinaa"}

Edelläkävijöiden haasteet ovat jollakin tapaa universaaleja ja yhteisiä. Polku on usein yksinäinen ja kivinen. Toimiminen "omassa uskossaan" vaatii rohkeutta ja määrätietoisuutta sekä toisinaan barrikadeille nousemista. Parhaimmillaan innostaja ja suunnannäyttäjä "antaa keskusteluun sytykkeitä, ärsyttää lempeästi ja heittää tulta”, kuten Leena Kurjenkin tiedetään tehneen. Machiavellista hän kirjassaan toteaa, että tämä löydettiin varsinkin angloamerikkalaisessa maailmassa 500 vuotta liian myöhään, "kun 
taas Blairin johtajuusaika oli ymmärrystä saadakseen kaksikymmentä vuotta liian aikaisin.” Niin myös Leena Kurjen uudistuksellinen ajattelu on herättänyt vastarintaa ja kritiikkiä.

Teorian ja käytännön vuoropuhelun toteutuminen vaikuttaa ikuisuushaasteelta niiden molempien arkiympäristöissä: Kuinka rakentaa toimiva yhteys niin, ettei kumpikaan ole vähemmän kuin toinen? Olisiko parhaan mahdollisen vuoropuhelun muodostaminen mahdollista toisiinsa tukeutuen, asiantuntijuutta jakaen ja yhteiseen hiileen puhaltaen? Kuten Kurki kirjansa aloittaa: "On turha kirjoittaa sellaista tieteellistä tekstiä, joka ei käänny käytännöksi, ja on turha toimia puuhastellen käytännössä, jollei sille löydy teoreettista perustaa." Tätä ajatusta olen kantanut mukanani yli kaksikymmentä vuotta ja perustellut sillä omaa tekemistäni varsin menestyksekkäästi. Toivon, että jonakin päivänä myös Leena Kurki saa ansaitun tunnustuksen teorian ja käytännön vuoropuhelun merkityksen esiin nostajana niissä piireissä, joissa sitä tähän päivään mennessä ei ole osattu arvostaa. En malta olla siteeraamatta kirjaankin nostetuista japanilaisen johtamisen periaatteista viimeistä: "Jos haluaa tulla ihmiseksi, jolla on hyvä sydän ja hyvät tavat, pitää etsiytyä sellaisten seuraan, joilla ne jo ovat.”

Monikerroksinen ja kiinnostava kirja esittelee lukijalleen Leena Kurjen tietokirjailijan uraa ja sen tuotoksia. Kurki käsittelee teoksessaan teorioidensa muodostumista. Hän kuvaa matkaa, joka on pitänyt tehdä oivaltaakseen asioiden välisistä yhteyksistä ja niiden toisiaan rakentavasta luonteesta jotakin. Kirjassa kuvataan myös dialogien lopputulemia, tekoja, jotka syntyivät kohtaamisten voimasta. Teos avaa lukijalle laajan näköalan kirjailijan kokemuksiin, kohtaamisiin ja niiden synnyttämiin tulkintoihin. Ne yhdessä ovat rakentaneet suomalaista sosiaalipedagogiikkaa siihen suuntaan kuin se osin tällä hetkellä tunnetaan.

Laiskalle lukijalle tämä teos on ihanteellinen tapa perehtyä runsaaseen Leena Kurjen tuotantoon ja sen keskeiseen sisältöön. Teos avaa yhteyden kirjailijan elämään ja auttaa ehkä huomaamaan punaisen langan persoonan, tekemisen ja teorioiden välillä. Pidän tätä nerokkaana tapana esittää Kurjen sosiaalipedagoginen teoria, ajattelu ja ymmärrys yksissä kansissa ja vieläpä niin, että sitä on hermeneuttisesti, henkilökohtaisena kokemuksena, kenenkään vaikea kyseenalaistaa. Voidakseen ymmärtää tämän kirjan sanomaa ja Leena Kurjen sosiaalipedagogista orientaatiota, on tunnettava hänen persoonaansa ja ymmärrettävä hänen elämänhistoriaansa. Tämä yhtä aikaa helppo ja vaikea, selkeä ja monimutkainen sekä yksityiskohtainen ja leveällä pensselillä maalattu kirja kannattaa lukea. 


\section{LÄHTEET}

Haavisto, A.-M. 2021. Konseptin implementointi alueellisessa ehkäisevän työn toimintasuunnitelmassa. Lahti: Sosiaalialan osaamiskeskus Verso -liikelaitos. Saatavissa https://innokyla.fi/sites/default/files/2021-10/Ehk\%C3\%A4isev\%C3\%A4n\%20 ty\%C3\%B6n\%20toimintasuunnitelma_mallinnus_final_1.pdf (haettu 14.11.2021).

Leimio, S. 2021a. Ehkäisevän työn toimintakertomus 2017-2021. Lahti: Sosiaalialan osaamiskeskus Verso -liikelaitos. Saatavissa https://www.phhyky.fi/assets/files/2021/08/P-H_4WEhkaiseva_tyo_2017-2021_final.pdf (haettu 14.11.2021).

Leimio, S. 2021b. Päijät-Hämeen ehkäisevän työn toimintasuunnitelma 2021-2025 (ei julkaistu). 
228 - Sosiaalipedagoginen aikakauskirja, vuosikirja 2021, vol. 22 